\title{
European Economic Integration in Kosovo
}

\author{
Malush Krasniqi, PhD Cand. \\ Faculty of Management, Department of Economic \\ European University of Tirana \\ malushi07@hotmail.com
}

\begin{abstract}
Topics addressed, European economic integration, as well as with important phenomenon, which is facing Kosovo in recent years, since the post-war process. The process of international economic integration is one of the most important phenomena of the contemporary world economy. The trend of international economic integration is the reconstruction of the country devastated by war, is an undeniable necessity, the only reason to catch the trend of the world's economic development. Kosovo has a very favorable position, bridging the central Balkans with the possibility of Development extraordinarily large because the Europe could have connected in short way with two continents. The main goal: increasing economic cooperation, the creation of new strategies for accelerating the process, fulfilling the standards required in the EU, the extent of market economy, regulation of relations with neighbors, etc. Topics that will discuss is European economic integration, the way how to reach to where we want is a road with many challenges and barriers, with special emphasis will be elaborated the process of stable and association, agreements signed by Kosovo, always having as target strengths and weaknesses of these agreements in the economic aspect of the country. Republic of Kosovo, respectively, institutions and people, are fully committed to the European integration process with the intent to join the EU.
\end{abstract}

Keywords: economic integration, strategies, barriers, strengths and weaknesses of the process, the geographical position of Kosovo, etc.

\section{Introduction}

Almost every day we discussed Kosovo, as in electronic media and print media, politicians, analysts and publicists claiming that Kosovo's goal and dream is to become a member in the big European family. However, public opinion is very little informed about EU membership criteria to be met, deficiencies or difficulties we face, the stage we find ourselves, etc.

We, the Republic of Kosovo, are the newest country in the region and the only state that has no contractual relations with the European Union (EU). Above all, we strongly believe that the best way to build a modern state is through observance of rules and practices as defined by the EU. Therefore it is in the national interest of Kosovo to focus on rapprochement with the EU.

Currently, member states of the EU and the EU are giving clear signals that they intend to strengthen relations with Kosovo and that Kosovo is on track towards the EU. Indeed, Kosovo is preparing to enter a new stage of its relations with the European Union. Initially, Kosovo should be clear which are the three pillars of the EU that are the keystone to proceed further with the process of membership. Topiku of my topic is only about economic integration and political integration by combining legal only when it has to do in economic terms.

Kosovo needs to recognize the best history, strategies, requirements of European Union reforms.

European union flow between treaties and reform strategies. 
The Treaty on European Union (TEU) represents a new stage in European integration since it opens the way to political integration. It creates a European Union consisting of three pillars: the European Communities, Common Foreign and Security Policy (CFSP), and police and judicial cooperation in criminal matters (JHA). The Treaty introduces the concept of European citizenship, reinforces the powers of the European Parliament and launches economic and monetary union (EMU). Besides, the EEC becomes the European Community (EC).

\section{Treaty of Maastricht on European Union}

The Treaty on European Union (TEU), signed in Maastricht on 7 February 1992, entered into force on 1 November 1993. This Treaty is the result of external and internal events. At external level, the collapse of communism in Eastern Europe and the outlook of German reunification led to a commitment to reinforce the Community's international position. At internal level, the Member States wished to supplement the progress achieved by the Single European Act with other reforms. This led to the convening of two Inter-Governmental Conferences, one on EMU and the other on political union.

\section{Objectives}

With the Treaty of Maastricht, the Community clearly went beyond its original economic objective, i. e. creation of a common market, and its political ambitions came to the fore. In this context, the Treaty of Maastricht responds to five key goals:

Strengthen the democratic legitimacy of the institutions;

Improve the effectiveness of the institutions;

Establish economic and monetary union;

Develop the Community social dimension;

Establish a common foreign and security policy. ${ }^{1}$

\section{The EU pillar}

The first pillar consists of the European Community, the European Coal and Steel Community (ECSC) and Euroatom and concerns the domains in which the Member States share their sovereignty via the Community institutions. The process known as the Community method applies in this connection, i. e. a proposal by the European Commission, its adoption by the Council and the European Parliament and the monitoring of compliance with Community law by the Court of Justice.

The second pillar establishes common foreign and security policy (CFSP), enshrined in Title $V$ of the Treaty on European Union. This replaces the provisions of the Single European Act and allows Member States to take joint action in the field of foreign policy. This pillar involves an intergovernmental decision-making process which largely relies on unanimity. The Commission and Parliament play a modest role and the Court of Justice has no say in this area.

The third pillar concerns cooperation in the field of justice and home affairs (JHA), provided for in Title VI of the Treaty on European Union. The Union is expected to undertake joint action so as to offer European citizens a high level of protection in the area of freedom, security and justice. The decision-making process is also intergovernmental. ${ }^{2}$

\section{Policies}

The Treaty establishes Community policies in six new areas:

Trans-European networks;

\footnotetext{
1 http://eur-lex.europa.eu/legal-content/EN/TXT/?uri=URISERV\%3Axy0026

2 http://aei.pitt.edu/perl/search/simple
} 
Industrial policy;

Consumer protection;

Education and vocational training;

Youth;

Culture.

\section{Economic and monetary union}

The EMU puts the finishing touches to the single market. Economic policy consists of three components. The Member States must ensure coordination of their economic policies, provide for multilateral surveillance of this coordination, and are subject to financial and budgetary discipline. The objective of monetary policy is to create a single currency and to ensure this currency's stability thanks to price stability and respect for the market economy. The Treaty provides for the establishment of a single currency in three successive stages: the first stage, which liberalises the movement of capital, began on 1 January 1990; the second stage began on 1 January 1994 and provides for convergence of the Member States' economic policies; the third stage should begin by the latest on 1 January 1999 with the creation of a single currency and the establishment of a Central European Bank (CEB).

Monetary policy is based on the European System of Central Banks (ESCB), consisting of the CEB and the national central banks. These institutions are independent of the national and Community political authorities. Special rules apply to two Member States. The United Kingdom has not proceeded to the third stage. Denmark has obtained a protocol providing that a referendum shall decide on its participation in the third stage.

\section{Post-maastricht}

The Maastricht Treaty represents a key stage in European construction. By establishing the European Union, by creating an economic and monetary union and by extending European integration to new areas, the Community has acquired a political dimension.

Aware of the progress of European integration, future enlargement and the need for institutional changes, the Member States inserted a revision clause in the Treaty. To this end, Article N provided for an Intergovernmental Conference to be convened in 1996.

This conference culminated in the signature of the Amsterdam Treaty in $1997 .{ }^{1}$

\section{Amendments made to the treaty}

Treaty of Amsterdam (1997) The Treaty of Amsterdam increased the powers of the Union by creating a Community employment policy, transferring to the Communities some of the areas which were previously subject to intergovernmental cooperation in the fields of justice and home affairs, introducing measures aimed at bringing the Union closer to its citizens and enabling closer cooperation between certain Member States (enhanced cooperation). It also extended the co decision procedure and qualified majority voting and simplified and renumbered the articles of the Treaties.

Treaty of Nice (2001) The Treaty of Nice was essentially devoted to the "leftovers" of Amsterdam, i. e. the institutional problems linked to enlargement which were not resolved in 1997. It dealt with the make-up of the Commission, the weighting of votes in the Council and the extension of the areas of qualified majority voting. It simplified the rules on use of the enhanced cooperation procedure and made the judicial system more effective.

\footnotetext{
1 http://europa.eu/about-eu/eu-history/1945-1959/index_en.htm
} 
Treaty of Lisbon (2007) The Treaty of Lisbon makes sweeping reforms. It brings an end to the European Community, abolishes the former EU architecture and makes a new allocation of competencies between the EU and the Member States. The way in which the European institutions function and the decision-making process are also subject to modifications. The aim is to improve the way in which decisions are made in an enlarged Union of 27 Member States. The Treaty of Lisbon also reforms several of the EU's internal and external policies. In particular, it enables the institutions to legislate and take measures in new policy areas

This Treaty has also been amended by the following treaties of accession:

Treaty of Accession of Austria, Finland and Sweden (1994), which increased the number of Member States of the European Community to fifteen.

Treaty of Accession of Cyprus, Estonia, Hungary, Latvia, Lithuania, Malta, Poland, the Czech Republic, Slovakia and Slovenia (2003)This Treaty increased the number of Member States of the European Community from 15 to 25.

Treaty of Accession of Bulgaria and Romania (2005). This Treaty increased the number of Member States of the European Community from 25 to 27.1

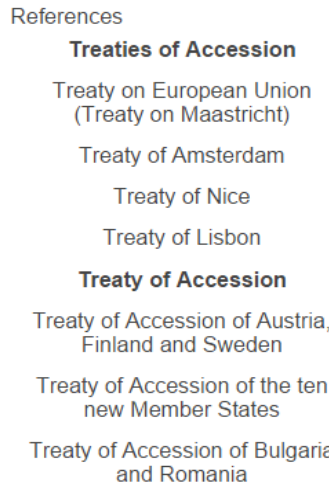

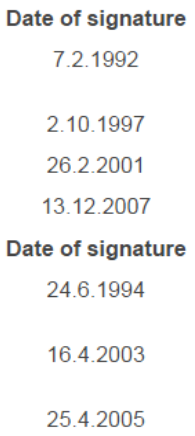

Entry into force
1.11 .1993
1.5 .1999
1.2 .2003
1.12 .2009
Entry into force
1.1 .1995
1.5 .2004
1.1 .2007

Official Journal

OJ C 191 of 29.7.1992

OJ C 340 of 10.11.1997

OJ C 80 of 10.3 .2001

OJ C 306 of 17.12.2007

Official Journal

OJ C 241 of 29.8 .1994

OJ L 236 of 23.9 .2003

OJ L 157 of 21.6 .2005

- Market integration

- It is a notion of behavior that indicates that market participation activities in various regions of the member countries are elaborated to supply and demand conditions in the entire union (or other relevant area). Usually, this will also be shown through significant cross-border movement of goods, services and factors. Even potential flows can be important in limiting the price of bidders or customer behavior. In a market with homogenous products or services or a type of financial market, market integration can be measured by the price level convergence.

- Trade agreements

- $\quad$ EU trade is to regulate Competition, Consumer Protection and Health through the Autonomous Trade Measures (ATM)

- During the year 2010. Based on the study of the European Commission for Kosovo, 2009, 2010 are preparations for signing a Free Trade Agreement (FTA) with the EU. However, after the publication of the Feasibility Study, in October 2012, it was decided that these preparations are integrated within the preparations for the signing of the Stabilization and Association Agreement (MTA)

- Develop trade with neighboring countries based on the support of rules and provisions stipulated in the agreement CEFTA

- $\quad$ SPP Kosovo has signed with the US and Norway, and Japan. Currently FTA was signed with Turkey.

\footnotetext{
1 http://eur-lex.europa.eu/legal-content/EN/TXT/?uri=URISERV\%3Axy0026
} 
- While the year 2015 is now signed eshe SAA agreement as a result of MTA and CEFTA. etc. ${ }^{1}$

\section{The effects of integration}

Effects of sustainable economic integration improve the efficiency of allocation of resources and the impact on production and consumption.

Dynamic effects have internal and external character. because they increase the efficiency of the market size growth. Integration turnaround in trading caused when the supply of moving products from countries that are not members of the economic pact in those countries which are. Regional integration is easier than global integration, because it is easy to promote the smaller regional cooperation. The benefits of free trade and economic integration achieved only if countries are ready to release something from independence and their autonomy.

Among the direct effects of integration, some authors list:

The effects on diversification of trade, ie changing the direction of foreign trade from a partner country in terms of another country;

The effects on the balance of payments;

The effect on government revenues;

The effects on consumer welfare, etc.

Naturally, the directions of these effects are varied, complex and proving increasing interdependence of the economy against the markets of European countries, particularly in cases where the country is a net importer, and with a weak economy and anemic in view of competition.

\section{Indirect effects}

Worth distinguished sectoral effects ie the impact on production, employment, trade, etc. Such are the effects on resource allocation and redistribution of income; effects on trade links; effects on improving the country's competitive position in the international arena; reducing the cost of commerce, etc. Meanwhile, global experience and our experience prove that European integration creates opportunities for increased domestic production, a wide breath business with private and foreign investment because European integration reduces the political risk of the country. Even this process also affects the ranking of the country by the specialized agencies, which in its turn equally serves as additional security for investors and international financial institutions, which plan to expand their activity in the Albanian economy.

\section{Levels of economic integration}

\section{Zone Trade Preferences}

Free Trade Zone

Union or Customs Union

Common Market; Economic and Monetary Union; Full economic integration²

\section{Why do we need economic integration?}

\footnotetext{
1 /www.president-ksgov.net

2 http://www.slideshare.net/mrcoder/101-ka-sht-integrimi-ekonomik
} 
The benefits of integration in the form of lowering costs of trading between member countries. Barriers required with other countries are common. Effects on prices, import competition and increase productivity. The benefit of regionalization versus nationalization.

\section{The benefits of European integration}

Various studies and the experience of countries that are already members of the EU or near it in comparison with Kosovo show that the main benefit to be expected of this process is the access or participation of Albanian exports in foreign markets, promotion of competitive structure and efficiency improvements related to that taken together in the long run will lead to the strengthening of the economy. While the estimated costs of this process mainly related to the change that brings the change from an "economy protected" in an open economy and competitive, which in its turn can not but lead to loss of income, and it also means job. In summary it can be said that in Albania, the prospect of being one day a member of the EU that has served and serves as an incentive to undertake economic reforms, social, political and legal rights in the years that have passed since the beginning of this processMeanwhile, in the preparatory process and in direct function of the European integration of Kosovo in recent years it has moved forward in the process of regional economic cooperation. Indeed, following the trajectory of the positions of the bureaucracy that the EU, against the Balkan countries the impression that despite the speed of the various process of European integration of countries of particular fixed in agreements of each country to the EU, sometimes regional cooperation dominates their cooperation with the Union individually. The least that can be said is that these two processes must go hand in hand and that regional economic cooperation remains a strong test for each country on the path of identification and security benefits of competitive and comparative advantages of their own. Unfortunately, the data on our economy, particularly on exports and their structure, show that the economy is still very weak, generally unable to compete with a number of countries in the region, while its products are, to a low quality.

\section{Conclusions}

Kosovo and the European Union have a strange relationship in which everyone wants and distrust other, at the same time. It's a new relationship, yet "without papers", which carries the potential to develop into a friendship that would result in the Kosovo part of the family of the EU; but also the potential to degenerate into a bitter feud that will continue long. The main problem between Kosovo and the EU is the conviction of each party that it is doing enough to approach the other party, while the other party is not interested what to look beyond its own yard. In Brussels, most of the officials dealing with Kosovo and the Balkans appear convinced that the EU is doing everything it can to bring Kosovo. Lack of progress for the visa liberalization issue, or negative perceptions in Kosovo for dialogue not seen in a negative context in Brussels. In fact, these are seen as part of a process totally free of politics, in which the EU is continually, rewarded Kosovo. EU officials in Brussels often ask almost angrily why Kosovo see so much of the United States, although the answer is equally simple - Kosovars watch more of those who believe they see and care for Kosovo more. Brussels does not want to accept that Kosovo is no competition. For now are the United States, but in the minds of many Kosovars EU competition other countries such as Turkey or Saudi Arabia. If the EU is sincere in the desire expressed to have Kosovo within its ranks, it is necessary to change the approach to Kosovo, at least to improve relations with the public, and explain better its position and its commitment In Kosovo. So far, the message that Kosovars receive from Brussels that the EU does not want Kosovo and Kosovars. For the citizens of Kosovo signs the last for this are isolation of Kosovo, not to liberalize the visa regime, as other countries of the Western Balkans, as well as the dialogue between Kosovo and Serbia, which seems to have been made only to reward Serbia but not Kosovo.

It is essential for the EU to speak more with the citizens of Kosovo and to show its commitment. Support for the EU in the minds and hearts of the citizens of Kosovo should be the most important for the EU. Until now, the EU is losing its battle with competitors to win the hearts and minds of Kosovars.

To distrust the European Union, Kosovo is even more responsible political class. Membership in the European Union really promoted as the main target of Kosovo politics. However, commitment and work that makes politics in Kosovo say the opposite. Politicians in Kosovo, but not only they, are convinced that the decisions in Brussels are purely political and is not really important how the standards achieved. While this is somewhat true in the case of the first waves of enlargement towards Eastern Europe, EU officials in Brussels make very clear that I will not make such mistakes. In the case of Croatia, the EU has not made any concessions and real state should satisfy conditions have paved Brussels. The same, the EU undertakes to do with all Western Balkan countries. These countries also are small and almost completely irrelevant to the 
EU. The only concern inflicted by immigrants from these countries, although this number has been reduced, due to the stringent measures that Member States have taken.

It is in the interest of Kosovo to develop new ways to communicate with these countries, new routes which will be preceded by the following recognitions. Best relations with these countries Kosovo would strengthen its prospects for EU membership, and would raise its voice in the international arena. The ways in which Kosovo can establish relationships with countries that have not recognized yet are different. Given the improvement of its image in the eyes of the public in these countries, taking into account the misconceptions they might have about Kosovo in general, we can do by using the famous personalities from different fields. Communication must also take place through representatives of society in common regional groups. Develop programs for the promotion of cultural or sports exchange. Seeing that these countries are important for Kosovo's relations with Serbia, it should have worked in this direction, showing a new spirit of cooperation with the citizens there. The opinion of the ICJ on the legality of Kosovo's statehood should be used as an additional argument for the recognition of these states. And to end what these countries need to keep a clear is that the recognition of Kosovo's statehood will not bring harm to any party, but in fact would contribute to creating a better cooperation between European countries.

\section{Reference}

"Integrimet ekonomike europiana" Prof. dr. Musa Limani

"Qeverisja dhe Politika e Bashkimit Evropian" Neill Nugent

"Evropa dhe Transformimi Ekonomik Kombetar: BE-ja pas Dekades se Lisbones Redaktuar” Mitchell P. Smith

http://eur-lex. europa. eu/legal-content/EN/TXT/?uri=URISERV\%3Axy0026

https://www. google.com/?gws_rd=ssl\#q=european+union+roles+for+economy+in+balkan

http://eeas. europa. eu/delegations/kosovo/eu_kosovo/political_relations/stabilisation_and_assocation_process/index_sq. $\mathrm{htm}$

http://armandi. info/ekonomik/Unioni-Evropian-se-Prezentimi-1. pdf

http://www. doktoratura. unitir. edu. al/wp-content/uploads/2014/06/Doktoratura-Halim-Bajraktari-Instituti-StudimeveEuropiane. pdf

http://filozofiku. uni-pr. edu/getattachment/Departamentet/Departamenti03/Hyrje-ne-institucionet-dhe-politikat-e-BE-seSH-B. pdf. aspx

UMI - FMN - Diplomaci Ligjerata të autorizuara nga Prof. Mr. Edita Tahiri dhe Ass. Mr. Bardhok Bashota

http://europa. eu. int/abc/history/index_en. htm\#top

http://aei. pitt. edu/perl/search/simple

http://www. te-nisemi-per. eu

http://www. uamd. edu. al

www. eulex-kosovo. eu.

http://eeas. europa. eu/delegations

www. eulex-kosovo. eu 
http://www. kcsfoundation. org

http://www. slideshare. net/mrcoder/101-ka-sht-integrimi-ekonomik

www. Menaxherat. com 